\title{
猃 壇
}

\section{現代「法学教育」の課題}

一問われる学部・大学院のありかた—

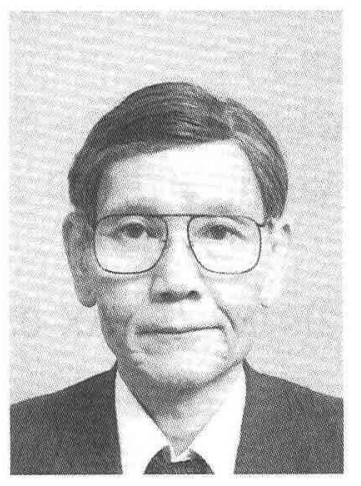

宮坂 富之助

I

いま大学では、学部そして大学院におけ る教育・研究のありかたが問われている。 すでに、この数年間にあいついで出された大学審 議会の審議・答申などへの対応にみられるように、 また、とりわけ国立大学についていえば、行政改 革の一環としてこれまでにない变革が迫られてい る。こうした状況は、現在の大学をめぐる直接の 背景であるが、大背景としての環境の変化として いえば、広く司法制度の改革の動向をはじめ、国 内外の経済・社会の大きな変容がある。

あらためていうまでもないことであるが、まず もって今回の司法制度改革の動向全体に関してい えば、本年7月に発足した司法制度改革審議会の課
題とされている諸問題は、すべてそれ自体として みれば、当然の対応措置である。しかし留意しな ければならないのは、本来、司法制度が国家の統 治機構としての重要な位置を占めるにもかかわら ず、例えば国の財政規模からみても国家予算の $0.4 \%$ 占めるにすぎない構造があることであり、 また、裁判制度をはじめ具体的な司法制度の全体 からみても、ますます「肥大化」する現代の行政権 あるいは立法権に対して、法治主義に基づく整序 機能を十分に発揮し得ない、との基本的な批判が あることである。改革にあたっては、まずもって、 そうした国民的な批判と期待に沿った慎重な検討 が求められているという、基本的な認識が前提に 
ならなければならない。

したがって、審議にあたっては、諸課題につい ての客観的な現状分析はもとより、「公論としての 位置づけを」・審議過程の情報公開を」などの要請 がよせられているのも、当然である。

本誌の編集委員会から「法学教育」に関する寄 稿を求められた。それは、こうしたかつてない急 速かつ根本的な改革課題を抱える大学教育の状況 が強く認識されているからであろう。日本学術会 議でも、このほど第二部の 50 周年記念の企画とし て、シンポジウム「法曹養成と法学・政治学教育 の課題」が開催されたのも、同趣旨による。

\section{II} 法学教育の領域では、いま、前記のよう な司法制度改革課題の重要な一環として、 法曹養成制度の根本的な検討課題がある。すでに 法務省・文部省をはじめ、日本弁護士連合会など弁 護士会そして主要な大学でも、この課題を学部・ 大学院の教育・研究組織のありかたとして急速に検 討を始めており、次第に成案へと練られつつある 状況にある。よく知られているように、従来から 裁判官・検察官そして弁護士は、難関とされる司法 試験を経て一定期間の司法研修の後に、それぞれ 法曹として育成されてきている(ちなみに、本年 99 年度の試験では、約1040名の合格者を数えてい る)。
このような状況にあって、当初、いわば制度の 基本理念に強く傾斜していた論議の内容は、次第 に練り上げられ、理念を前提にした具体的な制度 設計へと移っている。一言でいえば、現行の試験 制度を大幅に見直し、「より質の高い法曹を、より 多く養成するための新たな制度を、いかに設計す るか」であり、そのために、現行の法学部・大学院 における教育体制をいかに再編成するか、である。

\section{III} ところで、これは法律学関係者の間では よく語られることであるが、「法学教育」 とは何か、とりわけ時代背景を反映して、その内 容はどのように組み立てられるべきなのかである。 すでに述べたように、現在は「法学教育のありか たを全体としてみる」というよりは、「法曹育成」 制度という限られた制度領域からの視点で、その 課題が論じられている傾向が強い。

しかし、ここであらためて確認したいことは、 求められる法曹育成の目標はもとより、法学教育 のそれは、単に法律制度の知識だけでなく、それ を活かす能力と豊かな感覚、「多様な価值観をもつ 人間への理解と矛盾に満ちた社会構造への深い認 識」・多様かつ絶えず変容する社会・経済・政治 への知識と、必ずしも『先例』を求め得ない諸問 題への解決に努力し、対応する能力」などの培養 が強調されていたことである。またこれらは、こ 
れまで法学教育の領域で、いわゆる「リーガル・ マインド」の育成とされ、基本的に変わることは なかったはずである、ということである。

しかし戦後数十年を経て、新制大学の基本的な 枠組みのなかで、多くの主要な大学では、学部組 織の上に大学院を乗せながら、学部については社 会の要請と学生の進学意識に対応したカリキュラ ムの改革、大学院については本来の研究者養成に 加え、司法試験など多様な国家試験を志向する学 生や「社会人」学生を受け入れた体制を組むとい う構造にある。

前記のように、法曹をめざす学生は、相対的に 少数である。この意味では、多層化・多重化した 教育への要求に対応する過程で、前述のような法 学教育の目標・理念は、結果として、運営の面で 希薄化する。

\section{IV}

いま、前記のような法曹養成制度改革論 議のなかでは、諸外国の制度も比較検討 されている。とりわけ、現在約180校に達するとい うアメリカに打けるー・スクールの教育制度が 参考に值するという意見が強い。このような意見 に対しては「理念型としてはわかる」といった認 識評価がある。

たしかに、そこで展開されている教育方法面で の「ケース・メソッド」などに学ぶことが多いこ
とはいうまでもないし、そのこと自体は、周知の ことである。むしろ比較検討にあたって重要なこ とは、制度運営を支える法曹機関（例えば、Bar Associationなど）の関与のシステムや学部段階 での教育体系、司法制度と弁護士の社会的な役割 とその実像、市民の法意識など、多面的な分析の 上に立つという基本姿勢である。この点について いえば、R.Stevens、Law School-Legal Education in America from the 1850s to the 1980s, (The Univ.of North Carolina Press,1983) が非常に参考になった。そこでは、教育制度とそ の教育のありかたを歴史的な背景と結びつけて、 また、法律学の方法論の理論的な展開に即して、 大学関係者・法曹機関の対応の変化が、それぞれ 詳細に分析され、現在なお課題を残していること を語っている。

印象的であるのは、「専門的職業」としての弁護 士など法曹を志向する学生の期待に対応する教育 制度と、法学理論に基づく研究者養成制度のあり かたをめぐる意見との相克関係がみられることで あった。アメリカのロー・スクールの歴史的な展 開そして現実も、決して「平坦」ではなかったし、 いまも、そうではない、と感じた。 最後に強調したいことがある。すでに 1920 年代初頭に、この国の法学教育のあ 
りかたを論じた、末広篇太郎の基本姿勢である。 末広先生はその著『嘘の効用』(この著作は1988年、 冨山房から上・下巻として再録されている）で、 アメリカのロー・スクールに护けケース・メソ ッドの、教育方法としての有効性を論じ、判例研 究の重要性と「活きた規範の発見」を強調された ことで知られるところである。

私は、そのことはもとより、むしろ、その一連 のエッセイのなかで展開されている基本的な論旨 に、あらためて注目したい。例えば、「小智恵に捉 はれた現代の法律学」では、「人間味のある裁判は どうしたら出来るか」、「人間味のある法律はどう したら出来るか」、「もっと人間味のある法律の教 え方はないものか」と問いかけ、裁判所・裁判官 の基本的な姿勢を全人格的に問い、また法治主義 を実現するため、立法者が国民世論に耳を傾ける 謙虚さが必要であると、強調している。

また、戦後1951年に書かれた『法学とは何か』では、 「現在我が国の法学は、全体として科学的に体系化 されていない。教育の中心をなしている解釈法学 の教育にしても、ただ前からの伝統を追って行わ れているだけで、教育の本来の目的を十分に発揮 していないように思われる」として、科学の名に ふさわしい法学と法学教育を実現するために、「実 用法学」としての解釈法学と立法学の両者に通ず
る科学としての本質を「法政策学」に求め、その確 立に向けた法学の発展が必要であると強調している。

もちろん、末広先生のこうした一連の指摘は、 それ自体としてみれば、現在では研究者の間には 共有されているといってよい。例えば、かつて 「法律学の科学性」論が広く研究者の間で論議され たことを想起できる。また、先生が問題提起され た時代背景とは異なり、経済社会の状況も大きく 変わり、そのことを反映して教育の体系にも一定 の努力が加えられているのは事実である。

しかし、つとに指摘されているように、「社会の 『法化』」現象がますます進むなかで、先生が根底 で強調している法学の科学性を、研究そして教育 の領域で実現し得ているか、「学生の理性を満足せ しめ得るような法学教育」を行っているか、その ことが再度検討されねばならない。

法曹育成制度の根幹となるのは、まずもって学 部段階での法学教育の充実である。その上に立っ て、その前提の上に、大学院の教育体系の編成が ある。単なる職業教育に矮小化してはならないと 説いた先生の警告が今なお活きていることを、私 は強調したい。

宮坂 富之助（みやさか とみのすけ 1930年生） 日本学術会議第2部会員、社会法学研究連絡委員会委員、早稲田 大学法学部教授

専門 : 経済法学 